\title{
Port-related conflict at port of Gothenburg - consequences from a fashion retailer's perspective
}

\author{
Erica Lindroth, Hà Huong and Rickard Bergqvist * (D)
}

\begin{tabular}{l}
\hline * Correspondence: rickard. \\
bergqvist@gu.se \\
Logistics and Transport Research \\
Group, Department of Business \\
Administration, School of Business, \\
Economics and Law at the \\
University of Gothenburg, P.O. Box \\
610, 40530 Göteborg, SE, Sweden
\end{tabular}

610, 40530 Göteborg, SE, Sweden

\begin{abstract}
Previous research have distinguished the risks of supply chain disruptions and the negative effect of supply chain disruption on operational performance in terms of sales, costs and inventory. However, few researchers have studied supply chain risk management and strategies in relation to port conflicts. The 2016 port conflict at a major logistics port in Scandinavia, the Port of Gothenburg, posed an opportunity to study risk management and strategies in the context of major port disruptions, in this case, a labour conflict. The fashion retail industry was affected especially hard due to the short product life cycles and this paper, by means of case study method and analysis, investigates five cases in order to understand how they were affected and what mitigation strategies was used. Results illustrates that during the port conflict, the percentage of increase in logistics cost ranged between 15\% and $70 \%$, greatly affected by what mitigation strategy was used by the case company.

Keywords: Port conflicts, Risk management, Fashion industry, Supply chain disruption
\end{abstract}

\section{Introduction}

The port plays a crucial role in any global maritime supply chain as it links the martime leg with the hinterland. As such, the port is part of a sensitive global supply chain for many shippers. Most of the time, there are very little distrubances resulting from the port which makes them a relaiable part of the global supply chain. However, when there is a issue of port conflict for example, the impact and disturbance on the global supply chains is significant. Few researchers have studied supply chain risk management and strategies in relation to port conflicts. Gurning and Cahoon (2011) focused on the poor services related to port operation during disruption, although their research provided limited analysis of the impact on companies using the port. Hall (2004) and Carvalho et al. (2018) studied the effects of port disruption: Hall (2004) studied the 2002 West Coast Port lockout in the US; Carvalho et al. (2018) studied the strike at the Port of Lisbon in 2012. Their research acknowledged some consequences faced by companies using the ports. However, none of the authors discussed how differences in strategies affected the intensity of these consequences.

The 2016 port conflict at a major logistics port in Scandinavia, Port of Gothenburg, posed an opportunity to study risk management and strategies in the context of major port disruptions, in this case, a labour conflict. The conflict involved two trade unions

(c) The Author(s). 2020 Open Access This article is distributed under the terms of the Creative Commons Attribution 4.0 International License (http://creativecommons.org/licenses/by/4.0/), which permits unrestricted use, distribution, and reproduction in any medium, provided you give appropriate credit to the original author(s) and the source, provide a link to the Creative Commons license, and indicate if changes were made. 
that represent dockworkers and the employer APM Terminals, which began operating the container terminal at the Port of Gothenburg in 2012. ${ }^{1}$

The port conflict resulted in high uncertainty in the movement of containers and cargo. During 2017, container volumes at the port decreased by 19\% (Port of Gothenburg, 2017). The decrease was most drastic during the summer, when APM closed the container terminal for 6 weeks during evenings and night-time, to undermine Hamnfyran's ${ }^{2}$ industrial actions. Customers across Sweden decided to re-route their shipments, and container volumes decreased by 60\% during June alone (Bergsten and Makboul 2018). The effects of the port conflict hit the fashion retail industry especially hard. Due to its specific characteristics, the industry is very vulnerable to supply chain disruption (Christopher et al. 2004). Some of the attributes include short life-cycles, impulsive purchasing behaviour and volatile demand. This, combined with the fact that the case companies have a centralised distribution centre setup close to Port of Gothenburg which is also their gateway hub for imports from the Far East makes them very sensitive to disturbance at the port and hence a great opportunity to study port related supply chain disturbances.

The objective of the study is exploratory in nature with the aim of understanding what mitigation strategies shippers used to cope with the port related supply chain disturbances. The purpose of this study is therefore to investigate supply chain risk management and strategies in relation to port conflicts and the context of fashion industry retailers. This is accomplished by conducting in-depth case analysis of five companies with distribution centres located near the Port of Gothenburg heavily affected by the labour related conflict at Port of Gothenburg in 2016.

The paper is structured as follows: The section of "Literature review" analyses previous research addressing the issue of port related supply chain disturbances, mainly based on empirical observation. The section of "Methodology" explains the methods applied and introduces the cases included in the study. The section of "Empirical results" gives a detail account of the cases and how the experienced the period of port related supply chain disturbances. "Discussion and analysis" tries to synthesis on the results from the case studies with the aim of understanding what mitigation strategies shippers used to cope with the port related supply chain disturbances. Finally, "Conclusions" highlights the main conclusions from the study and case analyses as well as constructs some important hypothesis for further research.

\section{Literature review}

Previous researchers have distinguished the risks of supply chain disruptions (Norrman and Jansson 2004; Kleindorfer and Saad 2005; Chopra and Sodhi 2004; Wakolbinger and Cruz 2011) and the negative effect of supply chain disruption on operational

\footnotetext{
${ }^{1}$ At the beginning of their operation in Gothenburg, they signed a national collective agreement with the Transport Workers' Union. The Transport Workers' Union has approximately the same number of members on a national level as the Swedish Dockworkers' Union, but notably fewer locally in Port of Gothenburg (Ahlberg 2017). Without a collective agreement, the Swedish Dockworkers' Union is entitled to take industrial action, according to Swedish labour regulation. Despite representing most of the employees at the port, the Dockworkers' Union raised several complaints of being excluded from decision-making, which influenced their work environment (Helgesson, 2018; Svenska Hamnarbetarförbundet 2018). Measures such as employer blockades, downsizing, and additional strikes have been used to undercut each other's influence at the port (Gonzalez-Aregall 2018). The difficulty in finding an agreement between the parties is the backdrop for the long-lasting conflict (Sveriges Skeppmäklarförening 2017).

${ }^{2}$ The local section of the Swedish Dockworkers' Union at Port of Gothenburg
} 
performance in terms of sales, costs and inventory (Hendricks and Singhal 2005; Wilson 2007; Vilko and Hallikas 2011). Previous authors have defined supply chain disruption as a combination of unexpected and unintended events occurring upstream in the supply chain network, which threaten the business operation of the focal company (Bode and Macdonald 2017; Bode et al. 2011). Disruption risks refer to highimpact and low-likelihood risks, arising from natural or manmade disasters such as earthquakes, floods, terrorist attacks, labour strikes and fires that affect companies in a major way (Kleindorfer and Saad 2005; Chopra and Sodhi 2004). Specifically, supply chain disruption interrupts material flows, resulting in a sudden stop in the movement of goods (Wilson, 2017). Previous research has discussed some consequences of supply chain disruptions (Hendricks and Singhal 2005; Gurning and Cahoon 2011; Wilson 2007; Vilko and Hallikas 2011; Christopher et al. 2004; Carvalho et al. 2018; Hall 2004). These are categorised in Table 1 below.

Table 1 Consequences of supply chain disruption

\begin{tabular}{|c|c|c|}
\hline Consequences & Description & Authors \\
\hline \multirow[t]{4}{*}{$\begin{array}{l}\text { Transportation } \\
\text { network }\end{array}$} & $\begin{array}{l}\text { Longer distances of } \\
\text { transportation }\end{array}$ & \multirow{4}{*}{$\begin{array}{l}\text { Revilla and Sáenz } \\
\text { (2014); Hall (2004); } \\
\text { Carvalho et al. (2018); } \\
\text { Gurning and } \\
\text { Cahoon (2011) }\end{array}$} \\
\hline & Delay in transportation & \\
\hline & $\begin{array}{l}\text { Change in logistics } \\
\text { set-up (routing, } \\
\text { location of warehouse, } \\
\text { mode of } \\
\text { transportation) }\end{array}$ & \\
\hline & $\begin{array}{l}\text { Delayed handling of } \\
\text { cargo }\end{array}$ & \\
\hline \multirow[t]{8}{*}{ Logistics cost } & Increase in transportation & \multirow{8}{*}{$\begin{array}{l}\text { Gurning and Cahoon } \\
\text { (2011); Hendricks } \\
\text { and Singhal (2005); } \\
\text { Hall (2004); } \\
\text { Carvalho et al. } \\
\text { (2018); Vilko and } \\
\text { Hallikas (2011) }\end{array}$} \\
\hline & cost & \\
\hline & stemming from: & \\
\hline & $\begin{array}{l}\text { - Change in transportation } \\
\text { mode }\end{array}$ & \\
\hline & $\begin{array}{l}\text { - Change in transportation } \\
\text { routes }\end{array}$ & \\
\hline & - Expediting premium freight & \\
\hline & - Obsolete inventory & \\
\hline & $\begin{array}{l}\text { - Additional management } \\
\text { fees }\end{array}$ & \\
\hline \multirow{7}{*}{$\begin{array}{l}\text { Supply chain } \\
\text { performance }\end{array}$} & Increase in lead-time, & \multirow{7}{*}{$\begin{array}{l}\text { Scheibe and Blackhurst } \\
\text { (2018); Hendricks } \\
\text { and Singhal (2005); } \\
\text { Wilson (2007); Vilko } \\
\text { and Hallikas (2011); } \\
\text { Christopher et al. } \\
\text { (2004) Macdonald } \\
\text { and Corsi 2013) }\end{array}$} \\
\hline & Fluctuations in inventory & \\
\hline & Poor resource utilization: & \\
\hline & - Additional management & \\
\hline & $\begin{array}{l}\text { - Negative effect on team } \\
\text { stability }\end{array}$ & \\
\hline & - Inefficient decision making & \\
\hline & - Over-time & \\
\hline \multirow{5}{*}{$\begin{array}{l}\text { Commercial } \\
\text { aspects }\end{array}$} & Loss in sales & \multirow{5}{*}{$\begin{array}{l}\text { Hendricks and Singhal } \\
(2005) ; \text { Gurning } \\
\text { and Cahoon (2011) }\end{array}$} \\
\hline & $\begin{array}{l}\text { Deteriorating business } \\
\text { reputation }\end{array}$ & \\
\hline & Additional marketing & \\
\hline & Poor customer service & \\
\hline & Penalties to the customer & \\
\hline
\end{tabular}


Disruption of transportation flow can occur as a result of a subgroup of drivers, such as labour disputes, natural disasters, infrastructure failures and terrorist activities (Chopra and Sodhi 2004). When it comes to maritime related disruption, Gurning and Cahoon (2011) include delays, longer delivery time, deviations and the unavailability of maritime services due to port stoppages or no shipping services on specific routes.

Further, Hall (2004) investigated a specific case regarding the increase in transportation cost and change in logistics set-up. The 11-day shutdown of US west coast ports in the fall 2002, affected several industries, as shutdown included the six largest ports including Los Angeles, Long Beach, Oakland, Seattle, Tacoma, and Portland. These findings are in line with Gurning and Cahoon's (2011) suggested structure for disruption of a maritime event. Their model suggests that firms whose transportation networks involve maritime transportation may incur increased logistics costs when disruption occurs at a port. Hendricks and Singhal (2005) also discuss the increasing costs stemming from mismatches between supply and demand caused by transportation interruption, specifically how disruption can inflate the costs due to expediting, premium freight and obsolete inventory. Furthermore, as argued by Vilko and Hallikas (2011), additional management fees stem disrupted planning and management processes. These will add to the financial strain companies experience during a supply chain disruption.

Regarding the commercial aspect, Gurning and Cahoon (2011) and Hendricks and Singhal (2005) cited the loss of profit, loss of competitive advantage and deteriorating business reputation as consequences of a disruption event. Specifically, prolonged lead time due to the disruption is detrimental to customers' satisfaction as they cannot get the desired products as expected. This not only leads to short- and long-term loss of sales and market share but also to damaging a company's image. Furthermore, the disruption can lead to additional marketing and penalties paid to customers due to delivery delays. These aspects are especially evident given the supply chain characteristics of the fashion industry (Caro and Martínez-de-Albéniz 2015; Doyle et al. 2006; Fernie and Sparks 1998).

\section{Supply chain disruption risk management}

In managing supply chain disruptions, firms can use several tactics, including mitigation and contingency tactics (Tomlin 2006; Tang 2007). As reported by several major case studies (Closs and McGarrell 2004; Rice and Caniato 2003; Zsidis et al., 2001 and 2004), most companies are aware of the significance of risk assessment and employ different methods to evaluate supply chain risks. Nevertheless, most firms spend little time or resources for mitigation strategies. Estimates of the likelihood of the occurrence of specific disruptions and precise measures of the potential impact of each disruption are difficult to acquire due to the lack of data. Therefore, firms find it difficult to analyse costs and benefits to assess risk mitigation or contingency plans.

A commonly discussed risk management method in the fashion industry is agile supply chains (mainly flexibility in relation to market demand). Masson et al. (2007) examine how risk is managed among British fashion retailers and discuss unique features within the industry. Speed and flexibility are essential features for managing a complex supply chain and meeting market needs while minimizing penalties for failing to meet market demand. However, rapid changes in demand make supplying more risky and 
difficult. The short product life cycle increases the supply chain's exposure to risk. Oke and Gopalakrishnan (2009) investigate different types of risks faced by larger US. retailers. Their research provides a categorization of risks and appropriate risk mitigation strategies for dealing with risks within each category. According to the authors, mitigation strategies should include identifying points of vulnerability, examples of vulnerability points are bottlenecks, limited alternatives, geographic areas, insecure access to infrastructure, and a high degree of concentration in suppliers, manufacturing locations, material or information flows.

\section{Mitigation strategies}

A common practice to sell off perishable products or services is to use dynamic pricing (Tang 2006). Dynamic pricing and promotion are also effective in managing demand when supply is disrupted. Many authors refer to these initiatives as demand-switching strategies that provide incentives for customers to purchase other products instead of the unavailable, desired products due to disruption (Tomlin 2009; Tang 2006).

The strategy of assortment planning, which deals with products on display, their location, and visibility, has been used successfully by brick-and-mortar retailers to influence consumer behaviour (Tang 2006). A study by Teck-Hua and Tang (2001) performed at five supermarkets in the US demonstrated that the consumer's choice and demand could be altered depending on the number of facings for each product and its location on the shelves. This suggests that retailers can use assortment planning to attract customers to certain products. This strategy is useful during supply disruptions, where widely available products can be made more attractive to customers to mitigate temporary stock shortages (Tang 2006).

Tomlin (2009) describes the strategy of contingency sourcing as a mitigation strategy to deal with disruption. In this strategy, in the event of a supply shortage, firms search for products from their back-up supplier pool. Nejad et al. (2014) also discussed this strategy under the name contingency rerouting, described as a dual sourcing strategy with volume flexibility to overcome supply uncertainty. The supply chain setting includes a primary supplier which is cost-effective but prone to disruptions and a reliable but more costly volume-flexible backup supplier.

\section{Methodology}

The methodology applied in this research is best described as exploratory case studies. The nature of the topic and the context suggest an exploratory method for hypotheses generation and in order to gain in-depth knowledge, a case study design is preferable (Yin 2003). All interviews where recorded and transcribed in order to facilitate comparisons and analysis. For this study, the four fashion retailers was chosen for several reasons. Firstly, all four companies belong to the fashion retail industry, in which the products have a short life cycle, and thus short lead time is an important factor in their supply chain. Also, as these companies mostly have production points in low-cost labour countries such as Bangladesh, India, China, Turkey and Myanmar, the finished products are transported by sea to Europe for onward transport to their distribution centres. They all have centralised distribution centres located in regions close to Gothenburg as shown in Fig. 1 making them very valuable for disturbance at Port of Gothenburg. As Port of Gothenburg has a dominating market position in the container segment, especially to the Far 
East the case companies use the port as a main gateway hub-port. Because these companies' import activities rely on the Port of Gothenburg, studying them can provide in-depth understanding regarding the port conflict's impact on the fashion retail industry. All case companies are active in the segment of living fashion making them competitors. Figure 2 illustrates the alternative ports used by the companies during the lock-out of Port of Gothenburg in the summer of 2017. The companies favoured not to disclose their identity in the paper.

The case Jula $A B$ is added to allow comparison with the fashion retailers, because in 2013, Jula and DB Schenker established a virtual joint venture to facilitate the use of intermodal transport solution (Monios and Bergqvist 2015). In detail, a rail shuttle between the Port of Gothenburg and the inland terminal in Falköping were established to handle Jula's container flow in a more efficient and environmentally friendly way. The terminal in Falköping plays a role as a container depot. Jula's empty containers can be re-positioned to other exporting companies instead of being transported back to the port, which allows coordinated and consolidated container flows in the intermodal service as well as acting as a buffer to manage disturbances in the supply chain (Monios and Bergqvist 2015).

\section{Company a}

Company A has more than $90 \%$ of its production in Asia, with the rest in Turkey and Europe. It does not own the factories but purchases directly from its suppliers. The primary mode of transportation is by sea from Asia. The goods are transported directly

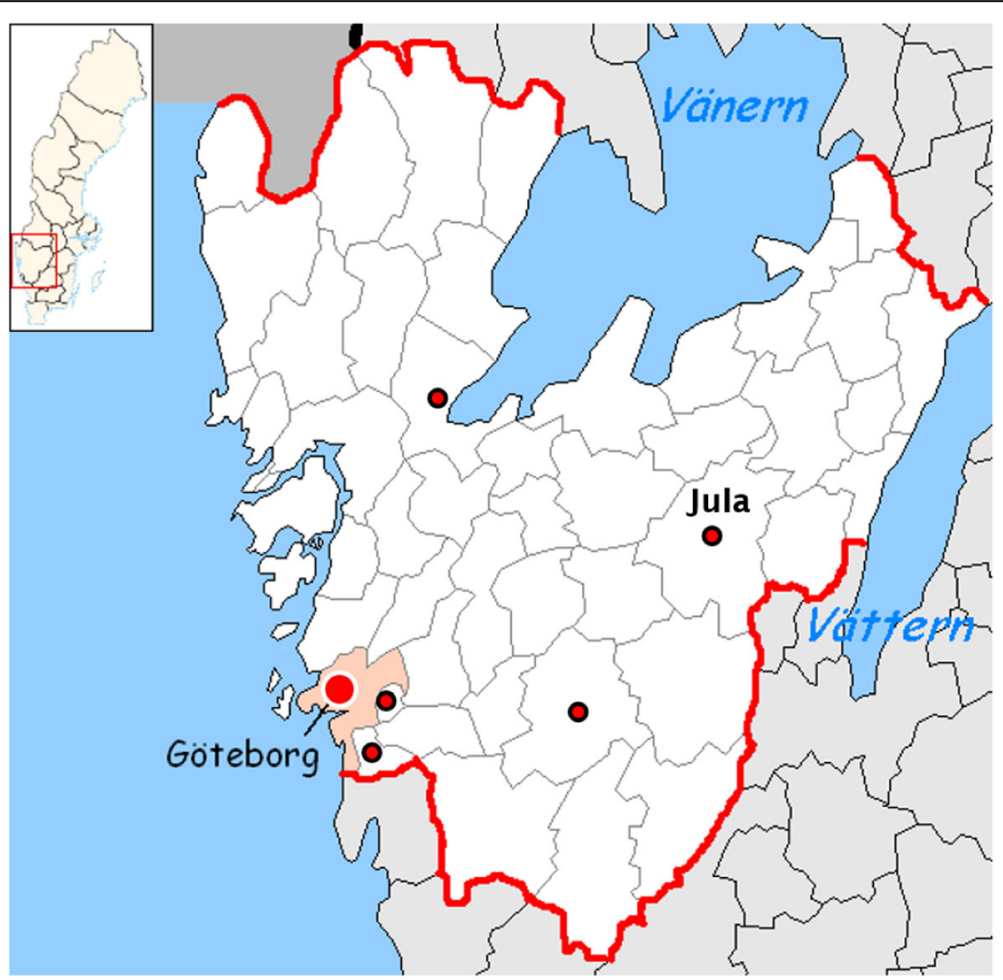

Fig. 1 The locations of distribution centres for Companies A, B, C, and D and Jula (Source: Sweden map blogspot, 2011) 


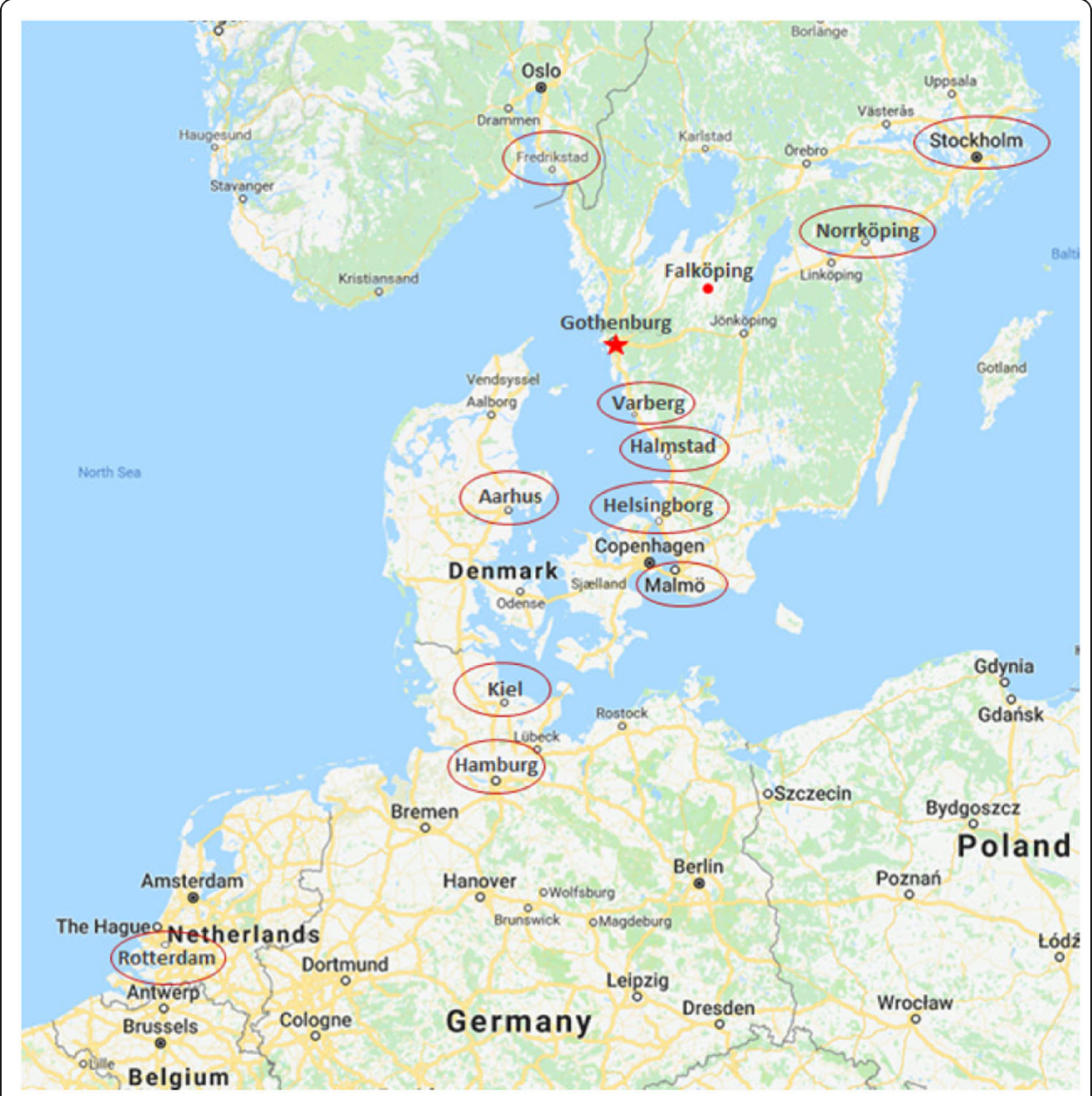

Fig. 2 The alternative ports used by the companies during the lock-out of Port of Gothenburg in the summer of 2017 (Source: Authors)

to the Port of Gothenburg in Sweden and then by truck to the distribution centre. Company A has two distribution centres (DC), one in Sweden and one in the UK. The DC serves the majority of Company A's markets in Sweden. The normal estimated lead time for goods to be delivered to the DC by sea from Asia is around 30 to 35 days depending on the location in Asia, and 20 to 22 days by rail. From Turkey, the lead time is around 10 days. The outbound lead time from the DC to the stores is one to 2 days depending on geographic location.

\section{Company B}

Company B sources its products mainly from Asia, but also from Turkey and Italy. Products are delivered primarily by sea from Asia, and some are transported by rail from China and Turkey. The company has two main DCs, one in Sweden and one in The Czech Republic, serving more than 450 stores in Europe. Once the products reach the Port of Gothenburg, they are transported by truck to the DC. The lead time for delivery of containers from Asian ports to Port of Gothenburg is approximately 40 to 45 days, while from China to Gothenburg by rail is around 16 days. The 
outbound lead time is about 2 weeks for new products to be available in stores before specific campaigns.

\section{Company C}

Company C sources approximately $90 \%$ of its products from Asia (e.g. China, Bangladesh and India) and $10 \%$ from Turkey. The containers are mainly transported to Gothenburg by sea from Asia and by train from Turkey. The lead time from Asia to the DC is estimated to be around 40 to 45 days, depending on departure port. From the port, the goods are transported by truck to the DC. This DC serves stores in eight countries, including Norway, Sweden, Finland, Denmark, Iceland, Poland, Germany and Austria. The DC is newly built and highly automated. The company strives to maintain a stable flow of products in and out. This set-up provides the most efficient operation for the company and good services for the stores according to the respondent.

\section{Company D}

Company D sources most of its products from Asia and ships them to Sweden via Port of Gothenburg. The containers are transported by truck to the DC after the arrival at the port. The DC serves stores in five countries, including Sweden, Norway, Finland, Denmark and Germany, and the e-commerce market in European countries. The estimated lead time for the transportation of the goods from Turkey to Sweden is roughly 8-9 days. Meanwhile, shipping the goods from Asian countries to Sweden takes about 34 to 38 days. Upon the arrival at the DC, the products are normally delivered to the stores within 2 days in order to prepare for the campaigns. For the basic assortments, the products may be stored in the DC longer for replenishment at stores when needed.

Jula

Jula operates in the DIY sector. As of 2016, the company has 94 department stores in three countries (Sweden, Norway, Poland) and about 3000 employees. In 2016, company turnover was $€ 0.6$ billion while profits reached $€ 60$ million. All flows are coordinated and consolidated at the $150,000 \mathrm{~m}^{2}$ central warehouse and distribution centre in Skara, Sweden. Most incoming goods to the central warehouse consist of imported containers, mainly from Asia. Schenker Air and Ocean in Sweden holds the Jula's key account and coordinates incoming container flows. All containers are transported to the Port of Gothenburg and from there, with an intermodal road-rail solution, to the dry port in Falköping (Sweden) and by truck $25 \mathrm{~km}$ to the DC in Skara.

\section{Empirical results}

This section describes and structures the effects experienced by the case companies during the port conflict and examples on how they address the circumstances and disturbances occurring. The first part is structured according to the categories outlined in Table 1 while the later part is chronologically structure according to the mitigation strategies used during different phases of the port conflict. 


\section{Transportation network}

During the summer of 2017, when there was a lock-out at the Port of Gothenburg, some shipping lines refused to enter the port, which caused a disruption in port operation. The interviewed companies managed the issues arising due to the port conflict in different ways.

Regarding Company A, due to proactive planning before the port event, they decided to use ports within Denmark and Germany instead of the Port of Gothenburg. This led to an increase in road transportation due to longer distances to the distribution centre. On the other hand, Company B did not choose to ship the containers to the other ports and relied on the carrier regarding the shipment of goods. During the conflict, the shipping lines refused to enter the port and unloaded the containers in different ports such as Varberg, Malmö, Aarhus and Fredrikstad. In more severe cases the shipping lines unloaded the containers in Germany, and longer distances were covered by truck in order to deliver the goods. As a result of the rerouted shipments, Company B had to use more road transportation compared to previously to pick up the containers in several ports. Besides, the respondent mentioned that there was a capacity restraint in both trucking and rail. Thus, it was challenging for Company $B$ to plan for the transportation during this period. The IT attack on Maersk was also mentioned by the respondent of Company B, it made planning even more difficult due to lack of information regarding the status of the container. In relation to the IT attack on Maersk, it is worth noting that all shippers and forwarders were greatly affected by the IT-attack since the terminal operator APM terminals in Gothenburg is an A.P. Møller-Mærsk A/S subsidiary.

Meanwhile, the two main alternative ports for the Company $\mathrm{C}$ during this time was Helsingborg and Aarhus using feeder vessels. For the goods that were still delivered in Port of Gothenburg, the interviewee mentioned a delay due to challenge of the limited working hours at the port, which meant the service level decreased and fewer containers were shipped in a timely manner. However, the company did not experience much difficulty as they were prioritized due to the size of the company. During the first 2 weeks, the respondent stressed that no one recognized the full effect of the port conflict and treated it as an ad-hoc situation. Thereafter, the difficulty increased in getting the trucks needed to transport the containers, due to the lack of capacity available. Additionally, this occurred during the peak season, making the situation even worse. The respondent also pointed out the IT attack on Maersk which caused an information disruption. It made it more challenging for the company to track the status of the containers in transportation. One of the difficulties was arranging the customs document in transit, due to the uncertainty of the delivery of the containers. In regard to Company D, the respondents perceived the consequences of the port conflict as modest, owing to their proactive re-routing solutions. In details, the containers were shipped to other ports instead of Port of Gothenburg, including Halmstad and Varberg in Sweden and some ports in Germany and Norway, followed by truck transport to the

DC. However, the interviewee also mentioned about the IT attack on Maersk, leading to the missing information regarding the status of the containers, which was considered as even worse than the port conflict itself. In addition, they also expressed the difficulty in getting truck transportation during the conflict.

As to Jula, during the port conflict, $80 \%$ of Jula's containers were still delivered to the Port of Gothenburg, and the rest were rerouted to other ports, including the Port of 
Stockholm, Malmö, Halmstad and Aarhus in Denmark. With the ability to reschedule the train operation, most of the containers were still delivered on rail to Falköping.

\section{Logistics cost}

All the interviewed retailers mentioned an increase in logistics cost during the port conflict, yet they were not willing to provide and publish specific cost increases related to specific types of shipments, etc. but preferred to only discuss it in general terms. However, an average estimation of the transportation cost was given by the freight forwarder. They suggested an increase of $70 \%$, which was equivalent to about 7000 SEK, in transportation cost per container for goods delivered from Asia to Port of Gothenburg. The increase in costs mostly stem from extra use of trucks and custom documentation. The uncertainty regarding the time of arrival also increased labour costs at the distribution centre due to poor work planning.

Company B added that the lack of structured information about the location to return the containers caused rising costs in transporting the empty containers. Additionally, if ships entered the Port of Gothenburg, Company B had to bear the surcharge fee for under-performance of the port added by the carrier. The respondent could not give any specific number for the increase in costs but emphasized that the increase was high for overall transportation costs. Additionally, the time consumed in tracking and arranging transportation of the containers, and low resource utilization added to overall costs. According to the respondent from Company $\mathrm{C}$, transportation costs increased during that period by 20 to $25 \%$. Specifically, the increase stemmed from additional trucking costs, detention cost for keeping the containers longer than the time allotted, fees at the port and feeder vessel costs. Similarly, the interviewees from Company D indicated that the trucking cost as the biggest increase in the total logistics cost during the time of port conflict. However, the situation was quite different with Jula when $80 \%$ of the cost increase came from the detention cost. Another $15 \%$ of the increase was attributed to the extra trucking cost to deliver the containers in some urgent cases. The rest of the cost increase stemmed from the demurrage fee $(2 \%)$ for picking up the containers late from the shipping lines and feeder vessels fee (3\%) from Hamburg, Rotterdam and Denmark. According to their respondent, the transportation cost went up by 2200 SEK per TEU, resulting in the total increase of $2.2 \mathrm{M}$ SEK. However, the rising cost was perceived as acceptable compared to the initial transportation cost of 14,700 SEK per TEU, taken into consideration that the goods need to be delivered to the market on time.

\section{Supply chain performance}

Related to supply chain performance, any aspect that affects the supply chain by means of affecting lead-times and reliabilty are included. Regarding inventory management, all companies have a replenishment system where goods are fulfilled directly after purchase in a store. For Company A, the port conflict postponed the delivery of goods roughly 1 week, causing a shortage in inventory levels and poor staff planning. Since supplying stores needs to be planned, uncertainty in delivery affects the whole operation. Concerning Company B, containers were sometimes delivered more than 2 weeks late, leading to poor utilization of equipment and human resources in the DC. Because 
Company B plans production based on the content of containers, missing information regarding their arrival made planning difficult.

Meantime, Company $\mathrm{C}$ experienced a delay in transportation which added at least 1 week to the total time of delivering the containers to the DC. The worst case was a delay of three to 4 weeks due to the backlog caused by the lack of trucking capacity. The backlog resulted in the need for overtime work in the DC to deal with it, at least 1 $\mathrm{h}$ in the morning and one in the evening for 6 weeks. Likewise, the respondents from Company D mentioned a small delay of around 1 week in the delivery of the products without any problem in inventory management. Jula had a delay of 14 days in transporting the containers to the DC due to the rerouting. However, according to the interviewee, the postponement did not affect the operation of the DC because Jula has the backup inventory to deal with the unexpected shortage of goods.

\section{Commercial aspects}

All respondents said it was difficult to measure sales losses; however, the respondent from Company A mentioned it was certainly more than the increase in logistics costs. Furthermore, he indicated that clothing products are often introduced under campaigns which are marketed to customers beforehand. Thus, it is important for all the items within a collection to be delivered on time before the campaign. Otherwise, the delay causes the loss of revenue and incurs the cost of obsolete products.

\section{Strategies during the port conflict}

From the exploratory case studies, the main strategy that all the interviewed companies used during this period was rerouting to alternative ports and accepting the incurred logistics costs to protect the sales at stores, by cooperating closely with their freight forwarder to solve the issues efficiently. In addition, the respondents emphasized the importance of information sharing among the involved parties, as information allowed the company to plan and act. Specifically, Company A managed to get the products delivered despite the overall shortage of trucks and drivers, by having contacts with several road hauliers in Denmark and Germany beside the contacts from their primary freight forwarder. Meanwhile, Company B tried to actively communicate with the carriers, the ports (mentioned Port of Malmö) to get the information regarding the status of the goods and come up with the solutions. Company $\mathrm{C}$ changed the normal working procedures with their freight forwarder in order to prioritize the main issues. Therefore, instead of having several meetings to chase information regarding the status of the containers, the company decided to have meetings with their freight forwarder twice a week. Lists of prioritized containers were given to the freight forwarder. In all cases, from the perspective of minimising added cost of the disturbances, all strategies used were to some extent successful but in comparison, the dry port strategy of Jula was the most successful strategy. The dry port strategy is analysed in more depth in the analysis part.

\section{Strategies prepared before the port conflict}

The respondent from Company A mentioned the uncertainty in the shipping industry (e.g. bankruptcy of Hanjin Shipping) and the difficulty in foreseeing these events. 
However, Company A conducts a risk assessment for several situations, such as accidents with ships.

Meanwhile, Company B conducts a risk assessment every year for better planning on lead time. From the risk assessment, it determines vulnerable points along the supply chain, for example, issues with air transportation from Bangladesh. Based on this, they try to come up with the solutions such as rerouting or changing the mode of transportation. Furthermore, the logistics department regularly cooperates with the purchasing department to review possible disruptions in transportation. As a result, the logistics department may suggest lengthening the lead time for delivery of products or increasing the quantity of future orders, which may lead to additional inventory costs.

Company $\mathrm{C}$ also conducts risk assessments, for instance, risks from sourcing, transportation from Asia or accidents within the warehouse. However, it does not have an excessive contingency plan specifically for port conflicts. Rather than having protocols for specific events, the company chooses to have closed discussions when problems occur. Based on the experiences of the port conflict, the respondent stated that there was always a way to transport goods to the DC. Furthermore, the sourcing department is informed about the risks of delay in transportation, to allow for extending the lead time.

Similarly, the respondents from Company D regarded risk assessment as part of their daily work, considering different routes and modes of transportation. Regarding the sourcing strategies, it was mentioned that the main categories are sourced both from Turkey and Asian countries to avoid the risk of supply disruption.

With regard to Jula, the respondent considers air transportation as a backup for urgent deliveries. Although, this option is not preferred due to the high costs associated with it. Instead, a dynamic approach is favoured and applied to eliminate risks of stockouts. To realise this approach, careful thought is put on the sourcing and information sharing. Therefore, the company has an integrated information system with their freight forwarder for their containers. The risk assessment does not include the investigation of alternative routes, which are considered as a responsibility of the freight forwarder and the shipping company.

\section{Changes in strategies after the port conflict}

All the respondents expressed that they saw no change in their strategies after the port conflict. Moreover, if a difficult situation like the summer port's lockout happens again, they prefer to continue the adopted solutions. The respondent from Company A expressed that he is more open-minded to alternative solutions regarding transportation. In reviewing the response to the port conflict, Company A considered its decision to reroute and use other ports instead of the Port of Gothenburg a successful solution. With regards to Company B, the respondent indicated that even if a port conflict escalates again, the company will continue to use the Port of Gothenburg as it is crucial to their import flow. The solution for transportation during a conflict would still be based on the prevailing conditions and suggestions from the carriers. However, the respondent emphasized learning from the previous port conflict enabled the start-up of arranging transportation to be shortened than before. Since the previous disruption contributed to a good routine and better knowledge in handling and prioritising orders. Yet, if a port conflict or similar disruption occurs on a 
long-term basis, Company B may consider switching ports or the sourcing of products and even changing the location of the DC. Because these decisions are strategic and not easy to make, the respondent hopes that any conflict will end.

Meanwhile, the respondent from Company $\mathrm{C}$ mentioned that the port conflict accelerated the company's intention to increase its use of the Port of Uddevalla to distribute the risk and deal with the peak season. For Jula, Port of Gothenburg is the preferred port with their logistics set-up. They would still apply the same strategy, since it was perceived as good. One possible alteration is to employ a logistics coordinator, who would take full control of the container flow and make sure the prioritized containers arrive on time.

\section{Discussion and analysis}

Several similarities can be found between the literature and empirical findings. Foremost, regarding logistics set-up, all the respondents expressed the need to re-route and increase the use of trucking. Along with the structure suggested by Gurning and Cahoon (2011), re-routing is a common consequence of maritime disruption events (such as port strikes). Indeed, one of the primary challenges the respondents expressed as related to the port conflict was arranging transportation from the alternative ports to their DCs, compared to their set-up with the Port of Gothenburg. The mentioned bottleneck created by limited trucking capacity displays a vulnerability point in their logistics set-up. Albeit trucking is often considered a flexible and low-cost option for transportation, when the port conflict caused multiple shipments to re-route, the limited service level of trucking as a mode of transportation led to issues in other parts of the supply chain for the interviewed companies. Considering the context of fashion retailers in desperate need of transportation services to deliver time-sensitive goods in a timely manner, this consequence of the port conflict highlights the severity of limited transportation capacity. Unlike previous research, the findings from these interviews point to the exhaustion of one mode of transportation by multiple actors during the disruption, which decreased their service levels and affected the fashion retailers negatively.

Furthermore, the respondents from the fashion retailers expressed difficulty in arranging transportation from the alternative ports due to lack of information regarding the location of the containers, which disrupted their ability to plan. The IT attack on Maersk heightened the challenges imposed by the port conflict, when the disruption of information meant that the status of containers was uncertain. Disruption of the planning process is similarly described by Carvalho et al. (2018) and MacDonald and Corsi (2013) when the effect of supply chain disruption causes inefficiencies in managing the logistics set-up. Although all the respondents mentioned the need for additional time to plan and manage the disruption, none of them mentioned the negative effect on team stability suggested by MacDonald and Corsi (2013). Instead, difficulty in coordinating with actors outside the focal company was mentioned; shipping lines and customs agencies in uncertain conditions was the main challenge.

Although previous research (Christopher et al. 2004; Vilko and Hallikas 2011) focused on the importance of lead time and discussed delay as a consequence of supply chain disruption, few researchers have, in detail, explained how lead time could be extended when a disruption occurs. Through the interviews with the retailers, some 
practical reasons for the extension in lead time due to the port conflict include prolonged time by using more truck transportation and time to resolve the backlog of containers due to the lack of truck capacity during the peak of the port conflict. Additionally, external factors not directly related to the port conflict can affect lead time. Among them is, for example, the IT attack on Maersk, emphasized by all the interviewees, which interrupted the communication flow regarding the status of the containers. Also, priority given to larger-size companies by the port can influence the speed and the order of picking up the containers at the port.

Regarding inventory and supply chain performance, respondents from Companies A and $\mathrm{B}$ mentioned a shortage in inventory needed at the warehouse due to the transportation delay caused by the port conflict. This result has been emphasized by many authors, including Hendricks and Singhal (2005) and Wilson (2007). Furthermore, Wilson (2007) discussed the increase in the number of goods in transit as a result of supply chain disruption, which was referred as a backlog in the case of Company C. On the other hand, although Jula had a 2-week delay in their lead time, they barely experienced any change in the warehouse's operation since Jula uses additional inventory and a buffer of containers at the dry port in Falköping to back up the shortage of goods in case of disruption. This also highlights the difference in inventory strategies among the distinct industries. For retailers in fashion industry, inventory backup is not likely to be an applicable strategy due to the risk of obsolescence, as suggested by Chopra and Sodhi (2004).

An estimate of the overall cost increase as shown in Fig. 3 has been made based on the information provided by the studied companies. This serves as an illustrative example, modelling the cost consequences. To begin with, the freight forwarder indicated that the average cost to transport containers from Asian ports to DCs in Sweden via Port of Gothenburg was 10,000 SEK per container. During the port conflict, the percentage of increase in logistics cost ranged between 15\% and 70\%. The lowest point was taken from Jula, as they had the least severe impact due to intermodal transportation set-up. Combing these numbers, the amount of rising cost fluctuated from 1500 SEK to 7000 SEK per containers. Given an example of a company with average 500 containers handled during the port conflict, the total cost increase could be estimated to be between 750,000 SEK and 3,500,000 SEK. This is equivalent to an increase between 62,500 SEK and 291,667 SEK per week.

With regard to commercial aspects, all respondents discussed loss of sales and obsolete stock. These possibilities were discussed by Gurning and Cahoon (2011) and Hendricks and Singhal (2005) and can be explained by the seasonal nature of fashion products (Christopher et al. 2004). Furthermore, the companies stressed the importance of availability at stores for all the items within a collection or a specific campaign.

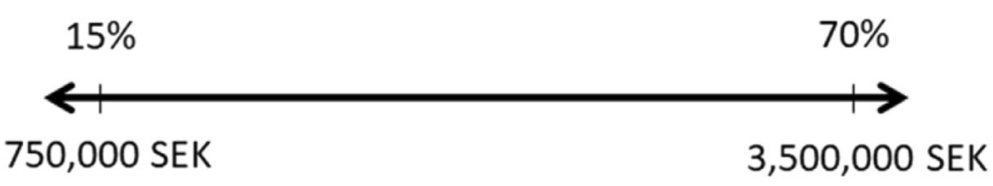

Fig. 3 The range of estimated cost increase in the transportation cost of a company with 500 containers during the port conflict summer 2017 (in percentage and amount) 
The shortage of one item may affect not only its sales but also the success of the whole collection.

As for mitigation strategies, the most common strategy respondents described is identifying vulnerability points by conducting risk assessments. However, none of the risk assessments from the interviewed companies involve the risk of port conflict. The lack of mitigation strategies from the interviews gives support to research by Closs and McGarrell (2004), Rice and Caniato (2003) and Zsidis et al. (2001, 2004) that companies which conduct risk assessments have not yet paid attention to mitigation strategies. However, there is a possibility that, due to the limitation of the research scope, only managers from logistics departments were involved. As such, it could be difficult to obtain a holistic view of the companies' strategies.

Regarding contingency strategies for the port conflict, none of the demand managementrelated strategies were mentioned by the respondents. Further, the contingency sourcing strategy was not evident in the studied cases as the case companies use offshore sourcing and have challenges ordering extra production in Europe due to the difference in capacity, quality, cost and expertise. In sum, all the case companies chose to act based on a reactive approach to the actual situation with a high dependence on solutions provided by their logistics service providers.

\section{Conclusions}

The fashion retailers faced several consequences during the conflict in Port of Gothenburg, which increased their overall logistics costs. The different strategies applied by the companies before and during the disruption resulted in varying degree of severity of the consequences. Flexible solutions are preferred by the fashion retailers and few changes have been made in their risk management strategies to manage disruption on a long-term basis. In relation to future disturbances, the current strategies are considered sufficient by most respondents. Considering the high costs incurred in transportation and the delay affecting the time sensitive goods of the fashion retailer, limitations exist in their strategies in terms of managing disruption. This is illustrated when looking at one of the primary impacts of the port conflict in Gothenburg, which was the exhaustion of trucking transportation when shipments were re-routed. The fashion retailers were more affected by this consequence compared to Jula who use both trucking and rail for the shipment of goods to their distribution centre. Furthermore, several risk management alternatives discussed by previous authors were not applied in practice by the companies. The limitations of applied risk management strategies may result in similar consequences if disruption happens again, and more severely if the disruption lasted during a longer period of time. Based on the results of this research, the following hypotheses are proposed:

- The risk management strategies applied by fashion retailers within logistics fail to mitigate risks from high impact/low frequent events, making them more vulnerable to these kinds of disruptions.

- In the event of a port conflict, the companies using intermodal transport experience less severe impacts in terms of logistics cost and transportation delay, compared to other companies.

- In the event of a port conflict, the companies having mitigation strategies experiences less severe impacts in terms of logistics cost, transportation, warehouse 
management and commercial aspects, compared to the companies without mitigation strategies.

From the perspective of managerial practise and implications, case analysis, clearly illustrates how the strategy of using a dry port have significant positive effect on mitigating supply chain disturbances. Obvious limitations of this study is the limited number of case studies and that only one port conflict period has been studied. The generic context of ports and their role in global supply chain suggest that the observations and conclusions could be useful in other port-related settings and research.

In regard to future research, several opportunities exist. Specifically, capacity constraints of transportation during supply chain disruption. Another observation is the effect of disruption on the retailer's ability to plan store layout.

\section{Acknowledgements}

The authors would like to thank all interviewees for their time and input to this study.

\section{Authors' contributions}

$\mathrm{EH}$ and $\mathrm{HH}$ collected and analysed the data and was major contributors for writing the manuscript. RB contributed in the writing and design of the study. All authors read and approved the final manuscript.

\section{Funding}

The research has been partly funded by the Swedish Transport Administration.

Open access funding provided by University of Gothenburg.

\section{Availability of data and materials}

The data from the study are available from the corresponding author on request.

\section{Competing interests}

The authors declare that they have no competing interests.

Received: 1 November 2019 Accepted: 6 February 2020

Published online: 21 February 2020

\section{References}

Ahlberg, K. (2017), "Swedish port conflict could lead to change in legislation". Nordic Labour Journal. Retrieved from: http:// www.nordiclabourjournal.org/nyheter/news-2017/article.2017-06-19.8859371100 (2017-01-19).

Bergsten, H., Makboul, L. (2018), "How the labour conflict in the Port of Gothenburg became of critical importance for the entire Swedish labour market". SVT Uppdrag Granskning. Retrived from: https://www.svt.se/nyheter/granskning/ ug/how-the-labour-conflict-in-the-port-of-gothenburg-became-of-critical-importance-for-the-entire-swedish-labourmarket (2017-01-19)

Bode C, Macdonald I (2017) Stages of Supply Chain Disruption Response: Direct, Constraining, and Mediating Factors for Impact Mitigation. Decis Sci 48(5):836-874

Bode C, Wagner SM, Petersen KJ, Ellram LM (2011) Understanding responses to supply chain disruptions: Insights from the information processing and resource dependence perspectives. Acad Manage J 54(4):833-856

Caro F, Martínez-de-Albéniz V (2015) Fast Fashion: Business Model Overview and Research Opportunities. In: Agrawal N, Smith S (eds) Retail Supply Chain Management. International Series in Operations Research \& Management Science. Springer, Boston: MA, p 223

Carvalho, H., Machado, V.H., Barroso, A, Garrido Azevedo, S. Cruz-Machado, V (2018), "Resilience of Logistics Service Providers Facing a Port", Proceedings of the International Conference on Industrial Engineering and Operations Management Bandung, Indonesia, March 6-8, 2018. PDF: http://ieomsociety.org/ieom2018/papers/106.pdf (2018-03-01).

Chopra S, Sodhi MMS (2004) Managing risk to avoid supply-chain breakdown: By understanding the variety and interconnectedness of supply-chain risks, managers can tailor balanced, effective risk-reduction strategies for their companies. MIT Sloan Manage Rev 46(1):53-61

Christopher M, Lowson R, Peck H (2004) Creating agile supply chains in the fashion industry. Int J Retail Distrib Manage 32(8): 367-376

Closs D, McGarrell E (2004) "Enhancing Security Through the Supply Chain", IBM Center for the Business of Government Special Report Series, April

Doyle SA, Moore CM, Morgan L (2006) Supplier management in fast moving fashion retailing. J Fashion Mark Manage 10(3): 272-281

Fernie J, Sparks L (1998) Logistics and retail management, insights into current practice and trends from leading experts. Kogan Page, London, UK

Gonzalez-Aregall M (2018) "Description of the Gothenburg container port conflict and its logistics consequences", Logistics and Transport Research Group, University of Gothenburg, Working Paper Series 2018:1

Gurning S, Cahoon S (2011) Analysis of multi-mitigation scenarios on maritime disruptions. Marit Policy Manage 38(3): $251-268$ 
Hall PV (2004) We'd have to sink the ships: Impact studies and the 2002 west coast port lockout. Econ Dev Q 18(4):354-367. https://doi.org/10.1177/0891242404269500

Hendricks KB, Singhal VR (2005) An empirical analysis of the effect of supply chain disruptions on long-run stock price performance and equity risk of the firm. Prod Oper Manage 14(1):35-52

Kleindorfer PR, Saad GH (2005) Managing disruption risks in supply chains. Prod Oper Manage 14(1):53-68

Macdonald J, Corsi T (2013) Supply Chain Disruption Management: Severe Events, Recovery, and Performance. J Bus Logistics 34(4):270-288

Masson R, losif L, Mackerron G, Fernie J (2007) Managing complexity in agile global fashion industry supply chains. Int J Logistics Manage 18(2):238-254

Monios J, Bergqvist R (2015) Using a "virtual joint venture" to facilitate the adoption of intermodal transport. Supply Chain Manage: An Int J 20(5):534-548

Nejad E, Niroomand I, Kuzgunkaya O (2014) Responsive contingency planning in supply risk management by considering congestion effects. Omega 48:19-35

Norrman A, Jansson U (2004) Ericsson's proactive risk management approach after a serious sub-supplier accident. Int J Phys Distrib Logistics Manage 34(5):434-456

Oke A, Gopalakrishnan M (2009) Managing disruptions in supply chains: A case study of a retail supply chain. Int J Prod Econ 118(1):168-174

Revilla E, Sáenz M (2014) Supply chain disruption management: Global convergence vs national specificity. J Bus Res 67(6): $1123-1135$

Rice B, Caniato F (2003) "Supply chain response to terrorism: Creating resilient and secure supply chains", Supply Chain Response to Terrorism Project Interim Report. MIT Center for Transportation and Logistics, MIT, Massachusetts

Scheibe K, Blackhurst J (2018) Supply chain disruption propagation: a systemic risk and normal accident theory perspective. Int J Prod Res 56(1-2):43-59

Svenska Hamnarbetarförbundet (2018)," Frågor and svar om situationen på APM Terminals", Retrieved from: http://hamn.nu/ article/2430/ (2017-01-19).

Sveriges Skeppmäklarförening (2017), "Föreningen i debatt med Hamnfyran", Skeppsmäklarnytt. Nr 32017.

Tang C (2006) Robust strategies for mitigating supply chain disruptions. Int J Logistics Res Appl 9(1):33-45

Tang CS (2007) Robust strategies for mitigating supply chain disruptions. Int J Logistics: Res Appl 9(1):33-45

Teck-Hua H, Tang C (2001) A Modeling Framework for Category Assortment Planning. Manuf Serv Oper Manage 3(3):191-210

Tomlin B (2006) On the Value of Mitigation and Contingency Strategies for Managing Supply Chain Disruption Risks. Manage Sci 52(5):639-657

Tomlin B (2009) Disruption-management strategies for short life-cycle products. Naval Res Logistics (NRL) 56(4):318-347

Vilko JPP, Hallikas JM (2011) Risk assessment in multimodal supply chains. Int J Prod Econ 140(2):586. https://doi.org/10.1016/j. ijpe.2011.09.010

Wakolbinger T, Cruz JM (2011) Supply Chain Disruption Risk Management through Strategic Information Acquisition and Sharing and Risk-sharing Contract. Int J Prod Res 49(13):4063-4084

Wilson M (2007) The impact of transportation disruptions on supply chain performance. Transportation Res Part E 43(4):295-320

Yin RK (2003) Case study research: design and methods. Calif, Sage Publications, Thousand Oaks

\section{Publisher's Note}

Springer Nature remains neutral with regard to jurisdictional claims in published maps and institutional affiliations.

\section{Submit your manuscript to a SpringerOpen ${ }^{\circ}$ journal and benefit from:}

- Convenient online submission

Rigorous peer review

- Open access: articles freely available online

High visibility within the field

- Retaining the copyright to your article

Submit your next manuscript at $\boldsymbol{\nabla}$ springeropen.com 